\title{
LAND SURVEYING STUDIES IN BUILDING CONTROL SYSTEM FOR SMART CITIES
}

\author{
G. Yalcin ${ }^{1, *}$ \\ ${ }^{1}$ Geomatic Engineer, 80000, Osmaniye, Turkey (drguleryalcin@gmail.com)
}

KEY WORDS: Smart City, Building Control System, Earthquake, Land Surveying, Geomatic, Legislation, Turkey.

\begin{abstract}
:
"Earthquakes" may cause dangerous results for people, which can damage buildings and hurt people, and may even cause death. Turkey lays down in a highly earthquake-prone region. Earthquakes are unpredictable and uncontrollable natural events; however, the people have to find ways to reduce these damages on people. One of the ways is to build "earthquake-resistant buildings". It is also one of the main necessities to build smart city under the focus of housing quality, quality of life. In this paper Building Control System in Turkey is presented in the frame of the legal basis in a general view. Also surveying documents related to building control system are introduced because land surveying studies are compulsory-preliminary works before building construction.
\end{abstract}

\section{INTRODUCTION}

A smart city engages its citizens and connects its infrastructure electronically. It manages the city's assets such as schools, libraries, transportation systems, hospitals, housings, power plants, local information systems and other community services, but not limited (Musa, 2016). The characteristics and factors of a smart city are: smart economy (competitiveness), smart people (social and human life), smart governance (participation), smart mobility (transport and Information and Communication Technologies-ICT), smart environment (natural resources) and smart living (quality of life). Quality of life includes cultural facilities, health conditions, individual safety, housing quality, education facilities, touristic attractivity and social cohesion (Johannes, 2019).

One of the necessities to build a smart city is to focus on housing quality under smart living (quality of life) because disasters such as earthquakes can be fatal to human life, the environment and infrastructure. Disaster management measures need to be preventive and reactive, in order to minimize the destruction of the disaster. It can be considered as a set of the planning and managing of the activities in any disaster phases (Shah, et al., 2019).

Turkey is one of the earthquake-prone countries, more that $90 \%$ its land lays down in highly seismic regions (Çağatay, 2005). Earthquakes are unpredictable and uncontrollable events that occur infrequently in any one location and several countries live earthquake disasters (McRae et al., 2018). Because of the earthquake disasters, many people die and many buildings collapse or heavily damage. Although the earthquake disasters are unmanageable and irrepressible, their damages can be mitigated. The investigations show that the main cause of the destructions and hazards is not the earthquake itself, but the result is hazardous because of the inappropriate production of the structures. To reduce fatalities in an earthquake the most important issue is "earthquake-resistant buildings" as a key preventative measure against earthquake damage (McRae et al., 2018; Bayram et al., 2018).
In Turkey, one of the ways for earthquake-resistant buildings is "Building Control Systems" (BCS). BCS aims to provide qualified buildings that are suitable for zoning plan, science, art and health standards as mentioned in Zoning Law numbered 3194. Zoning Law aims to ensure the design of settlement places and buildings according to plan, science, health and environmental conditions in the view of life and property security. At this point, aim of Zoning Law numbered 3194 is intersected with Building Control Law numbered 4708.

Plans and works on land (building floors) are important as well as the construction of buildings. Before building construction some surveying and cadastral works must be done in the frame of Building Control Law and its Application Regulation, Zoning Law and Planned Areas Type Zoning Regulation. In this study surveying and cadastral procedures and their documents are determined and presented according to mentioned legal basis in the view of "zoning" and "map application responsibility".

\section{BUILDING CONTROL}

"Structure" is a work that surrounds people and goods in terms of volume, and protects the living and the goods from external influences (Akman, 1982). However, "building" is a finished and ready structure to be used or still used (Y1lmaz, 2002; Law 3194). The buildings are the focus of human life in the past as well as today. Structures that ensure the safety of life and property can be cause of the damage to life and property due to some natural disasters if not designed and built in accordance with regulations related to earthquake. The first aim of building control is to prevent the occurrence of damages in buildings due to earthquakes and other natural disasters. The second one is to minimize damages that cannot be avoided.

(Yılmaz, 2006; Karaoğlu, 2011; Sakallı, 2008) presents a wide history on building control. It shows that "building control" is not an independent subject in the current legislation in Turkey prior to 1999 Marmara Earthquake. It is dealt with the existing legal regulations and generally within the rules of zoning law. Building control is regulated according to Zoning Law numbered 3194 and "building control activity" is made by a civil engineer or an

\footnotetext{
* Corresponding author
} 
architecture. The name of the application is called as "technical responsibility system". The first independent regulation on building control is brought to law with the Decree Law numbered 595 on Building Control which is issued after 17 August Gulf and 12 November Düzce Earthquakes in 1999 (1999 Marmara Earthquake). Finally, Building Control Law numbered 4708 is enacted in 2001 (Yavuz, 2015).

Within the scope of "Building Control Law numbered 4708" all kinds of buildings are subject to the supervision of the Building Control Companies that have legal personality working with the permission obtained from Ministry of Environment and Urbanization and which are exclusively engaged in building supervision. "Building Control Companies" have served in all of Turkey's provinces for construction and control issues related to build more robust and durable structures in Turkey. This law aims to provide project and construction control for building quality constructions that are appropriate for zoning plan, science, art and health rules and standards, and also to regulate the principles and procedures as in (article 5/1) in (Regulation, 2008). The Building Control Companies carry out the building control services by the auditor architects and auditor engineers. Control personnel and assistant control personnel support auditor architects and auditor engineers. In this way, it is possible to talk about three groups that have presence in a building control organization: First is "founding partners" (administrative personnel), second is "auditor architects and engineers" (technical staff) and third is "control personnel and assistant control personnel" (technical staff) in (Regulation, 2008).

\section{Also (Regulation, 2008) declares that:}

A partner in a building control company must have a degree on architecture, civil engineering, mechanical engineering or electrical engineering in (article 10/1),

On the project phase, Building Control Company checks "zoning status document", "application chart", "title deed record", "ground study report" and other necessary documents related to the parcel, where the building will be built in accordance with the legislation and keeps the copies in the file according to (article $5 / 2-a)$

On the construction phase of the project, the company ensures to determine "corner points of the parcel" under the supervision of the relevant administration and applies them on the land in accordance with the "plan of site" in (article 5/4-b).

The most effective way to keep the building construction under control is to obtain prior permission for all kinds of construction and reconstruction activities. Permission, named as "building license" in application, is the certification of the audit by a public process (Y1lmaz, 2002; Y1lmaz, 2006). If there is no deficiency or inaccuracy, building license is issued by examining the documents, which are the basis of the application for building permits and which are given with the appropriate opinion by the related building control company ((article 4/3) in (Regulation, 2008)).

"Title deed record" is an initial document containing brief information about property ownership and property such as parcel number, block number, name of city, district/village, area, reason of acquisition...etc. A file with 57 listed title documents is prepared to have a building license. Among them, Application Chart (Original), Zoning Status Document, Plan of Site, Plankote (Dimensional Drawing) (Original), Elevation Location Chart,
Independent Department Plan, Surveying Chart are completed by surveying and cadastre engineers.

\section{BCS AND LAND SURVEYING STUDIES IN TURKEY}

In Turkey the works and activities are carried out through the collaboration of various concerned government and private sector authorities. Building Control (BC) studies are executed by Environment and Urbanization Provincial Directorates under Ministry of Environment and Urbanization. Branch Office, that is responsible for BC studies, in Environment and Urbanization Provincial Directorate mainly aims to execute works and procedures which are determined in the frame of Building Control Law numbered 4708 and related regulations (Osmaniye Çevre ve Şehircilik İl Müdürlügü, 2018). On the other hand, "land surveying studies" has an important part before building construction for building control. In Turkey surveying and cadastral services are carried out by "Cadastre Offices under General Directorate of Land Registry and Cadastre" and "Licensed Offices of Surveying and Cadastre (LOSC)". After 2005 cadaster sustainment services are transferred to "LOSCs" in another name "private sector". LOSCs have the responsibility of both making and controlling the services for non-registered services. Responsibility to make these services belongs to LOSCs while responsibility to control the services and documents belongs to Cadastre Office (Yalcin and Ates, 2016). There are 81 Cadastre Offices, 973 Land Registry Offices (TKGM, 2020) and 228 Licensed Office of Surveying and Cadastre for the services and activities in Turkey (LİHKABDER, 2020).

\section{SURVEYING DOCUMENTS FOR BUILDING CONTROL/BUILDING LICENSE}

The work order is "the confirmation of the zoning plans", "the confirmation of the parceling plan", "the project confirmation", "the preparation of building license" and "building use document" respectively. After the confirmation of the zoning plans scaled 1/1000 and the confirmation of the parceling plan, the procedures are registered to land registry notebooks and "title deed" is given to the concerned person or institution. And then the construction is done on mentioned parcel under the conditions specified in the zoning plan (Türkiye Belediyeler Birliği, 2018). For building license 57 needed documents are listed as in (Table 1) at the end of the paper. Some of them which are completed by Surveying and Cadastre Engineers after land measurements are presented with examples: Application Chart, Zoning Status Document, Plan of Site, Plankote, Elevation Location Chart, Independent Department Plan, Surveying Chart.

"Application Chart" (Figure 1) is a result of "Application" process. "Application" is a marking process of the boundaries of ownership or easement on the ground in accordance with the cadastral information and documents. This chart is prepared before the construction starts and it includes numbers of block and parcel, corner points and their coordinates with the descriptive information as in title deed and also information and signs of preparing and controlling people. Finally, the coordinates of the related parcel are applied to the ground.

Zoning status document is the document containing the basic zoning information such as Whether the construction can be carried out, Whether the parcel has a partnership with the adjacent parcels, Whether the parcel is adjacent or split; if it is split, the front yard, the backyard and the side garden distances of the plot, Whether the parcel is in a commercial or residential area, Whether there is a left to the road or not, Whether merge/allocation is needed, Coefficient for floor area, Coefficient 
for floor space, Maximum building height, Ground safety information, Width and length of the parcel, Height of subbasement (Figure 2). This document is provided by Technical Department related to Zoning/Map in Municipality. In fact, "zoning studies" is one of the main working branches of the surveying engineers. Surveying engineers must obey Zoning Law numbered 3194 and related sub-regulations while producing zoning maps. Zoning maps are controlled and confirmed by surveying engineer in Cadastre Office and sent to Municipality for second confirmation. The zoning status documents are provided to the person or institution concerned according to this final zoning map by Municipality Zoning/Map Department.

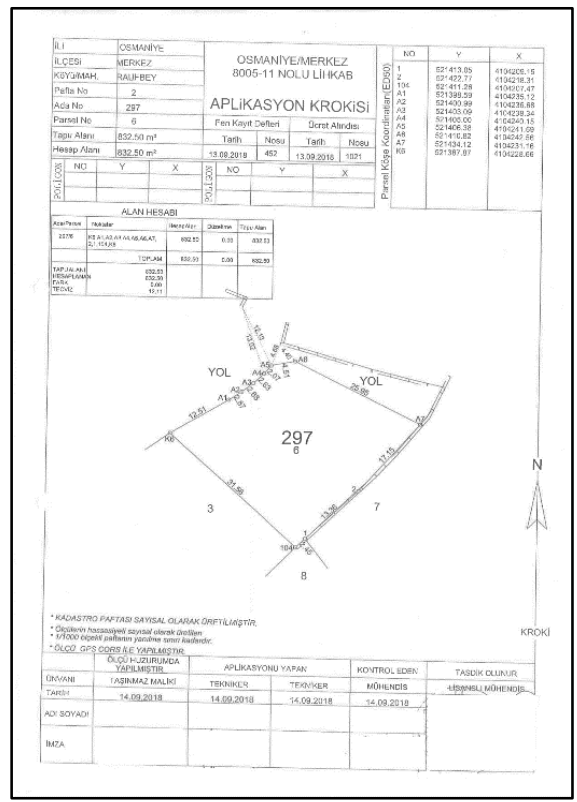

Figure 1. Application chart (sample form Osmaniye, Turkey)

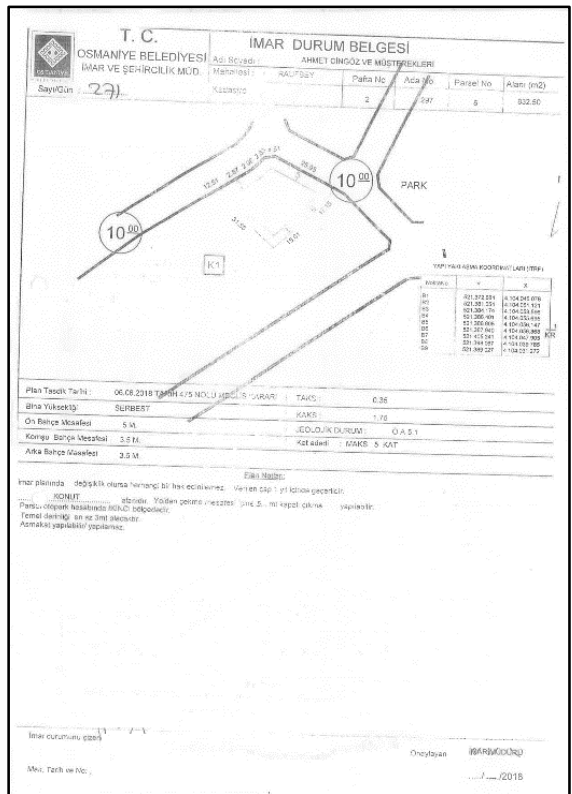

Figure 2. Zoning status document (sample form Osmaniye, Turkey)

Plan of Site (Figure 3) is the plan that shows the boundaries of the building to be started to the neighboring parcels and the boundaries to the roads from the top. It includes many elements in the details; electric pole, telephone lines, water lines, parking lots, entrance gate of the building, entrance direction of the plot, road condition, trees etc. The locations of these items are created with this plan.

Plankote (Figure 4) is a map that covers all details together with the topographic situation of the land, which is designed to form a base for the projects. Land elevations ( $\mathrm{Z}$ coordinates with $\mathrm{X}, \mathrm{Y}$ coordinates) are surveyed at certain intervals or by connecting to a fixed point as parcel-based or on a specific area. Surveying engineer who has a survey-engineering office may prepare this Plankote.

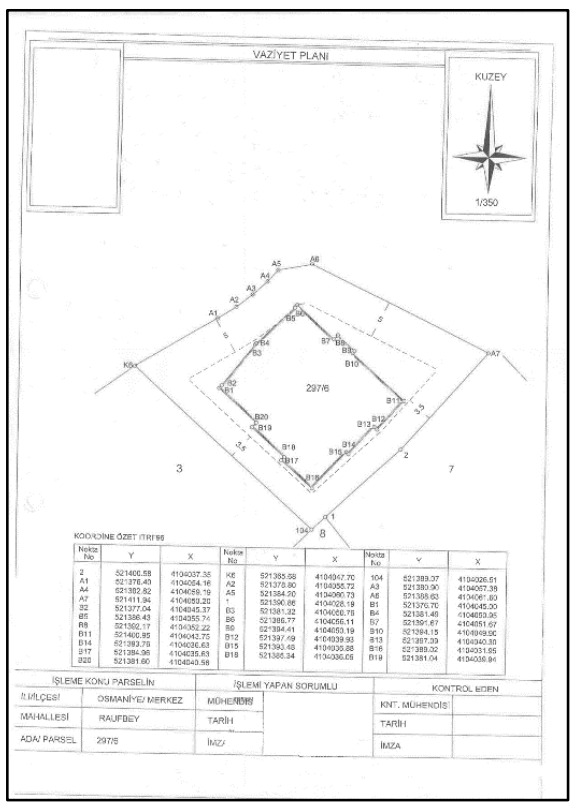

Figure 3. Plan of site (sample form Osmaniye, Turkey)

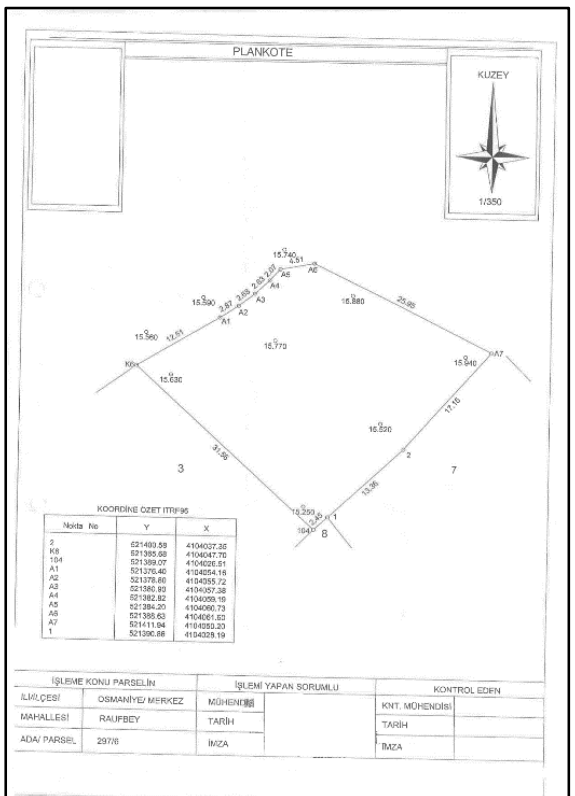

Figure 4. Plankote (sample form Osmaniye City in Turkey)

Elevation location chart is a chart that includes the elevation values of each floor of the building and also there is a special part that presents the location of the building in the parcel with the $\mathrm{X}$ and $\mathrm{Y}$ coordinate values (Figure 5). 
An independent department must be suitable stand-alone use and must have qualifications such as apartment, store, shop, warehouse, etc. And also the plot share independent department floor must be reserved/determined. Independent department plan/chart shows the basic positions of the structures and its additions, technical infrastructures, based on floor easement or condominium. It is arranged with the measurements in settlement projects based on building license. The measurements are tied to the ground control points, the digital and vector lines comply with the legislation.

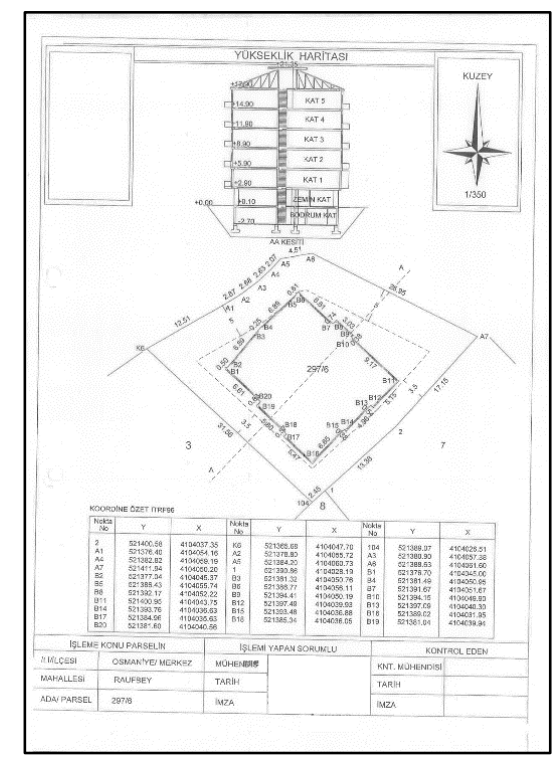

Figure 5. Elevation location chart (sample form Osmaniye, Turkey)

Surveying chart (Figure 6) consists the boundaries, corner points' coordinates of the parcel and the building ground. It shows the location of the building in the parcel with block and parcel number, the adjacent parcels with the parcel numbers, all corner coordinates, all length values, and also benchmarks. It is needed for "building permit document" after the building is completed.

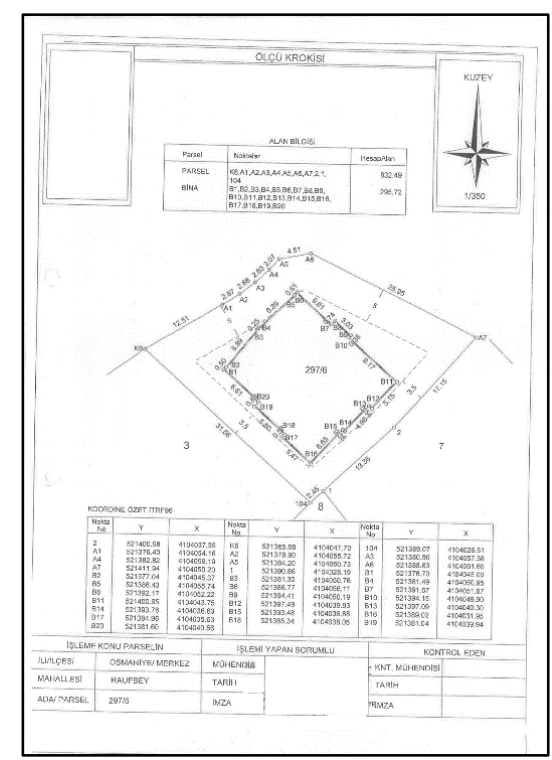

Figure 6. Surveying chart sample form Osmaniye, Turkey)

\section{EVALUATION}

It is clear that building controls are the responsibility of Provincial Directorates of Environment and Urbanization under Ministry of Environment and Urbanization. However, while inspecting building control applications, it is necessary to examine the organizations that take/should take an active role in the building control system, and also it is necessary to determine and examine the duties, powers and responsibilities of these organizations. These organizations can be classified as Municipalities, Professional Chambers such as Chamber of Surveying and Cadastre Engineers, and other official institutions. Municipalities are the most active organizations in the construction sector. They have the responsibility to select residential units, to apply urbanization and zoning regulations, to allow construction of buildings, to supervise them during construction, to give these buildings a construction license, settlement permit, issuance license. Chamber of Civil Engineers and Chamber of Architects under Union of Chambers of Turkish Engineers and Architects is a professional chamber in the building/construction sector. The duties and responsibilities under the supervision of these chambers are limited to the fact that only the members of their own members and members are supervised on a project basis. Due to the lack of legal regulations, the related chambers carry out this supervision work without any sanctions. The institutions (health, education, military, etc.) without a building control unit/department execute the building investments with bid method on behalf of that institution (Güneş et al., 2011).

Construction is performed with interdisciplinary cooperation. Also building control system has an interdisciplinary process and responsibility with architectures, civil engineers, electric engineers and mechanical engineers (Regulation, 2008; Law 4708; Gümüşburun and Öcal, 2016; Tantekin and Ünal, 2017). Besides surveying engineers carry out important roles to establish strong, healthy and safe buildings, especially against to earthquakes, with their ground works. Surveying documents help for static and architectural projects. Surveying and Cadastre Engineers are responsible on Technical Applications. These engineers who produce the related technical application documents (such as application charts, site plans, plankote...etc) must be registered to Chamber of Surveying and Cadastre Engineers, it means that they must be member of the chamber.

Civil engineers create a static project for the structures to stand. This project consists of layouts showing the structural system elements with their dimensions and diameter, length and quantity of the steel reinforcements. In order not to have any problems in the construction application, it is necessary that the production and construction workers/masters must dominate this project. And it is surely that the static project must be prepared in accordance with the architectural project (MEB, 2019). One of the important problems faced by the building control firms during the project application/implementation and inspection is mismatch among architectural projects, static projects and installation projects such as for electricity, water and natural gas (Gümüşburun and Öcal, 2016; Tantekin and Ünal, 2017). Before creating the static project, Application Chart is done by surveying engineers and then Location Application of the Constructions/Buildings is implemented. The transfer of the corner points of a building on the site or location plan by using the application elements obtained from the plan is called the application of the building. It is known that every step-in engineering studies has and also requires an accuracy. The surveying measurement method and criteria are selected according to the requested accuracy. It should not be disregarded 
that the application may vary depending on the precision (accuracy, sensitivity), the measurement method and the criteria to be chosen, and may cause great damages in the future. It is therefore important. The geometry designed in an engineering service must be transferred to the land to meet the desired accuracy (GISHARITA, 2019). Plankote and Site Plan studies must have the required accuracy and precision as in Application Chart and Location Application studies. At the start Plankote must be compatible with the ground. Otherwise it is likely to have problems during Location Application of the Construction/Building. Elevation values ( $\mathrm{Z}$ coordinates) that are measured in surveying studies are important as horizontal coordinates ( $\mathrm{X}$ and $\mathrm{Y}$ coordinates).

A subbasement is a floor or level beneath the main basement (entrance level, zero level) of the building, however it is not buried to the land. This section may be a floor on which the structure is placed, or simply the surface of the basement floor. The main purpose of the subbasement is to protect the structure from natural threats such as moisture, water, floods and rains. They are made according to the terrain and climatic conditions. Subbasement is identified as "Ground floor base elevation: The upper level of the floor of buildings" in (Regulation, 2017). According to the regulation, if there is no provision contrary to zoning plans, the subbasement level cannot fall below \pm 0.00 . For building permission and control, "subbasement license" is another required procedure such as licenses for application of the building, basement license, license for heat insulation, rough construction license and floor easement license. According to the articles 32 and 42 in law numbered 3194, the upper floors/departments are not built without subbasement license. On the other hand, in article Temporary Topic 2 rules that levelling studies such as subbasement levelling are made according to the applications in adjacent parcels/adjacent order buildings. (Adjacent order is a kind of the building order which is adjacent to the building to one or more parcels and which has exit from common area to backyard.) If there is a subbasement levelling difference between adjacent buildings, building columns cut each other and joint place between building column and building beam breaks during the earthquake. It means that especially slab concrete damages to the columns of the other structure in the adjacent order, column beam joints, carrier system of reinforced concrete structure with earthquake force if there is a levelling difference depending on subbasement level or floor level.

\section{CONCLUSION}

Some characteristics such as qualities, minimum human control and use of advanced digital systems for/in the buildings are expected from smart buildings in smart cities. In this view building related qualities are focused on energy management and space utilization. Also, this quality list can be expanded with other qualities such as working efficiency, employee well-being, environmental impact, waste management, specific technology, etc. But beyond all that, strong, robust, healthy, safety and earthquake-resistant buildings are needed for smart cities and for their infrastructure.

While it is possible to reduce the effects of disasters before the disaster with technical and some other measures which are possible to be taken, large losses in earthquake disasters have occurred so far in Turkey. Disaster management needs to be managed well to reduce the damage of disasters. It comprises four basic phases: harm reduction, preparedness, intervention and improvement. These basic phases can be addressed in an integrated way and disaster losses can be reduced. Also, organizations' own working principles, interoperability among the organizations, data sharing, data standards, technology, human resources, staff and public education, are other important factors for disaster management. It is clear that "building" and "building control" base on a multidisciplinary basis. All these disciplines such as civil engineers and geomatics engineers (land surveyors) have special importance in their branches. While technical details are executed, the legal provisions must also be considered.

Land surveying processes are done technically and technologically. However robust buildings are under the responsibility of different occupation disciplines such as local municipalities, Ministry of Environment and UrbanizationBuilding Control Commission, building control private sector, owners, contractors and building material laboratory. Lack of continuity in building inspection, audit gap, lack of qualified personnel, cost concerns, non-compliance of building materials with relevant standards and technical specifications are some of the problems encountered (Bayram et al., 2017; Tantekin et.al., 2017; Pala and Demir, 2017; Erdiş and Gerek, 2011).

In Turkey legislation on Building Control came into force in 2001 to increase the quality of building production. It is clear that all organizations should fulfill their responsibilities to build healthy structures and infrastructure, and also data and information should be included in digital environment and shared with related organizations.

\section{ACKNOWLEDGEMENTS}

Author thanks to Lecturer Celal Bicakci for supporting example figures that belong to Osmaniye City and Lecturer Harun Ozkaya for supporting with his experiences on civil engineering applications.

\section{REFERENCES}

Akman, G. S., 1982. Taşkın İnşaat. İstanbul Üniversitesi Yayınları, İstanbul.

Bayram, S., Aydınlı, S., Budak, A., and Oral, E., 2018. Türkiye'de yap1 üretiminde ve denetiminde yaşanan etik sorunlar. Pamukkale Üniversitesi Mühendislik Bilimleri Dergisi, 24(3), 461-467. DOI: 10.5505/pajes.2017.65481.

Çağatay, İ. H., 2005. Experimental evaluation of buildings damaged in recent earthquakes in Turkey, Engineering Failure Analysis, 12, pp. 440-452. DOI: https://doi.org/10.1016/j.engfailanal.2004.02.007.

GISHARITA, 2019. Temel aplikasyonu. http://www.gisharita.com/insaat/temel-aplikasyonu. (10 January 2019).

Erdiş, E. and Gerek, İ..H. 2011. Yap1 denetim sisteminde karşılaşılan sorunlar ve çözüm önerileri. TMMOB İnşaat Mühendisleri Odası 6.İnşaat Yönetimi Kongresi, 25-26-27 Kasım 2011, Bursa.

Gümüşburun A. G. and Öcal, M. E. 2016. Türk inşaat sektöründe mimari tasarım süreci hataları ve nedenleri. Erciyes Üniversitesi Fen Bilimleri Enstitüsü Dergisi, 32(1), 21-28.

Güneş, M. E., Özen M. and İhtiyar, M. A., 2011. İmar uygulamalarında yapı denetimi ve teknik uygulama sorumluluğu, M.S. Thesis, Zonguldak Karaelmas Üniversitesi, Türkiye. http://www.academia.edu/2400300/Yap\%C4\%B1_Denetim_ve 
_Teknik_Uygulama_Sorumlulu\%C4\%9Fu_TUS_(19 January 2019).

Johannes, M., 2019. Smart city and urbanization challenges. https://www.e-zigurat.com/blog/en/smart-cities-urbanizationchallenges/. (12 September 2020)

Karaoğlu, E., 2011. 4708 sayılı yap1 denetim kanununun denetimdeki verimliliği. M.S. Thesis, Yıldız Teknik Üniversitesi Fen Bilimleri Enstitüsü İnşaat Mühendisliği Anabilim Dalı Yapı Program1, İstanbul.

Law 3194, 1985. Zoning Law. Official Gazette Date 03.05.1985 $\begin{array}{llll}\text { and Official } & \text { Gazette } & \text { No. } & 18749\end{array}$ http://www.mevzuat.gov.tr/MevzuatMetin/1.5.3194.pdf $\quad$ (05 January 2019).

Law 4708, 2001. Law on Building Control. Official Gazette Date 13.07.2001 and Official Gazette No. 24461 . http://www.mevzuat.gov.tr/MevzuatMetin/1.5.4708.pdf $\quad$ (02 January 2019).

LİHKABDER，2020. http://www.lihkabder.org.tr/

September 2020)

McRae, C., McClure, J., Henrich, L., Leah, C. and Charleson, A., 2018. Reactions to earthquake hazard: Strengthening commercial buildings and voluntary earthquake safety checks on houses in Wellington, New Zealand. International Journal of Disaster Risk Reduction, 28, 465-474. DOI: https://doi.org/10.1016/j.ijdrr.2017.12.007

MEB, 2019. Milli Eğitim Bakanlığı İnşaat Teknolojisi Ahşap Kalıp Öncesi Hazırlı, Ankara. http://megep.meb.gov.tr/mte_program_modul/moduller_pdf/Ah \%C5\%9Fap $\% 20 \mathrm{Kal} \% \mathrm{C} 4 \% \mathrm{~B} 1 \mathrm{p} \% 20 \% \mathrm{C} 3 \% 96$ ncesi\%20Haz\%C4 $\%$ B1rl\%C4\%B1k.pdf (15 January 2019).

Musa, S., 2016. Smart cities-a road map for development. Journal of Telecommunications System and Management, 5(3). https://www.hilarispublisher.com/open-access/smart-cities--aroadmap-for-development-2167-0919-1000144.pdf. 12.0.9.2020. DOI: 10.4172/2167-0919.1000144.

Osmaniye Çevre ve Şehircilik İl Müdürlüğü, 2018. https://osmaniye.csb.gov.tr/mudurlugun-gorevleri-i-83893 (31 January 2018).

Pala, M. and Demir, M. S.., 2017. Güneydoğu Anadolu Bölgesinde yapı denetimi uygulamasında karşılaşılan sorunlar ve bu sorunlara ilişkin çözüm önerileri. Adıyaman Üniversitesi Mühendislik Bilimleri Dergisi, 6, 20-33.

Regulation, 2008. Application Regulation on Building Control. Official Gazette Date 05.02.2008 and Official Gazette No. 26778.

http://www.mevzuat.gov.tr/Metin.Aspx?MevzuatKod=7.5.1195 $\underline{1 \& \text { MevzuatIliski=0. }}$. (15January 2019).

Regulation, 2017. Planned Areas Type Zoning Regulation. Official Gazette Date 03.07.2017 and Official Gazette No 30113. http://www.resmigazete.gov.tr/eskiler/2017/07/201707038.htm. (15 January 2019).

Sakallı, F., 2008. Yap1 denetim sisteminde yaşanan sorunlar, 4708 sayılı yapı denetim hakkında kanun'daki eksiklikler ve çözüm önerileri, M.S. Thesis, İstanbul teknik Üniversitesi Fen Bilimleri Enstitüsü İnşaat Mühendisliği Anabilim Dalı Yapı İşletmesi Programı, İstanbul.

Shah, S.A., Seker, D. Z., Rathore, M. M., Hameed, S., Yahia, S.B. and Draheim, D., 2019. Towards disaster resilient smart cities: Can Internet of Things and Big Data Analytics be the game changers. IEEE Access Special Section on Urban Computing and Intelligence.

https://ieeexplore.ieee.org/stamp/stamp.jsp?tp=\&arnumber=875 9905. (12 September 2020). DOI: 10.1109/ACCESS.2019.2928233.

Tantekin, Ç. and Ünal, C., 2017. Yap1 denetim firmalarının sorunlarının belirlenmesi ve Adana örneği. Çukurova Üniversitesi Mühendislik Mimarlik Fakültesi Dergisi, 32(4), pp.71-78.

Tantekin, Ç. G., Aydınlı, S. and Cengizhan, Ü., 2017. Yap1 denetim firmalarının proje denetim ve uygulama sürecinde karşılaştıkları sorunlar. TMMOB İnşaat Mühendisleri Odası Uluslararası Katılımlı 7. İnşaat Yönetimi Kongresi, 06-07 Ekim 2017 Samsun. Kongre Sempozyum Bildiriler Kitab1, Erol Ofset, Vol. 1, No.1, 211-216.

TKGM, 2020. www.tkgm.gov.tr. (13 September 2020)

Türkiye Belediyeler Birliği, 2018. Yapı Ruhsat Süreçleri Rehberi. www.tbb.gov.tr. (12 November 2018).

Yalcin G. and Ates H. B., 2019. Experiences on Licensed Offices of Surveying and Cadastre (LOSC) in Adana, Turkey. The International Archives of the Photogrammetry, Remote Sensing and Spatial Information Sciences, Vol. XLII-2/W1, 2016 3rd International GeoAdvances Workshop, 16-17 October 2016, İstanbul, Turkey. Retrieved from https://www.int-archphotogramm-remote-sens-spatial-inf-sci.net/XLII-2W1/25/2016/isprs-archives-XLII-2-W1-25-2016.pdf, January 2019).

Yavuz, E., 2015. Yap1 denetim sözleşmeleri, $\mathrm{PhD}$ Thesis, İstanbul Üniversitesi Sosyal Bilimler Enstitüsü Özel Hukuk Anabilim Dalı, İstanbul.

Yılmaz, M., 2002. Imar Yaptırımlart Ve Yargisal Koruma, Seçkin Yayınları, Ankara.

Y1lmaz, H., 2006. Türkiye'de 1980'den sonra kent planlamas1 hizmetlerinin özel kesime götürülmesi eğilimleri: yapı denetim kuruluşları örneği, PhD Thesis, Ankara Üniversitesi Sosyal Bilimler Enstitüsü Kamu Yönetimi ve Siyaset Bilimi Kent ve Çevre Bilimleri Anabilim Dalı, Ankara. 


\begin{tabular}{|c|c|}
\hline No & TITLE OF DOCUMENT \\
\hline 1 & Application by Owner and Top Writing \\
\hline 2 & Copy of Related Title Deed \\
\hline 3 & Application Chart (Original) \\
\hline 4 & Zoning S tatus Document \\
\hline 5 & Plan of Site \\
\hline 6 & Plankote (Dimensional Drawing)(Original) \\
\hline 7 & Elevation Location Chart \\
\hline 8 & Independent Department Plan \\
\hline 9 & Surveying/Application Chart \\
\hline 10 & Chart with Bencmarks (Röperli Kroki) \\
\hline 11 & Zoning Document by Municipality \\
\hline 12 & Contract (Agreement) by Surveying Engineer \\
\hline 13 & Area Calculation \\
\hline 14 & Construction Declare (Architecture) \\
\hline 15 & Information Form for Building \\
\hline 16 & Service Contract for Building Control Responsible Office \\
\hline 17 & Commitment for Building Control Responsible Office \\
\hline 18 & Permission Document for Building Control Responsible Office \\
\hline 19 & Tax Board for Building Control Responsible Office \\
\hline 20 & Signature Circulars for Building Control Responsible Office \\
\hline 21 & Copy of Identity Card of Building Control Authority \\
\hline 22 & Contract between Building Owner and Contractor \\
\hline 23 & Copy of Identity Card of Building Owner \\
\hline 24 & Copy of Identity Card of Building Contractor Authority \\
\hline 25 & Registration Document to Chamber of Commerce of Building Contractor \\
\hline 26 & Signature Circulars for Contractor \\
\hline 27 & Tax Board for Contractor \\
\hline 28 & Commitment for Contractor \\
\hline 29 & The First Installment of the Building Control Service Fee \\
\hline 30 & Contract of Building Site Chief \\
\hline 31 & Commitment for Building Site Chief \\
\hline 32 & Copy of Identity Card of Building Site Chief \\
\hline 33 & Registration Document to Chamber of Building Site Chief \\
\hline 34 & Certificate of Residence of Building Site Chief \\
\hline 35 & Commitment for Architectural Project \\
\hline 36 & Commitment for Static Project \\
\hline 37 & Commitment for Mechanic Project \\
\hline 38 & Commitment for Electric Project \\
\hline 39 & Commitment of Surveying Engineer \\
\hline 40 & Commitment of Geology Engineer \\
\hline 41 & Commitment of Geophysics Engineer \\
\hline 42 & Ground Survey Report \\
\hline 43 & Architectural Project \\
\hline 44 & Static Project \\
\hline 45 & Static Calculation \\
\hline 46 & Electric Project \\
\hline 47 & Plumbing Project \\
\hline 48 & Thermal Insulation Calculation \\
\hline 49 & Elevator Avan Project (for 4 floors and up) \\
\hline 50 & Heating Installation Project \\
\hline 51 & Calculation and Report for Heating Installation \\
\hline 52 & $\mathrm{CD}$ (consists all projects) \\
\hline 53 & Project Control Form \\
\hline 54 & Hazardous Building Report \\
\hline 55 & Landscape Project \\
\hline 56 & Commitment for Landscape Project \\
\hline 57 & Commitment of Exterior Scaffolding \\
\hline
\end{tabular}

Table 1. Needed documents for building license 